\title{
PENGARUH LABA AKUNTANSI DAN ARUS KAS TERHADAP VOLUME PERDAGANGAN SAHAM PADA PERUSAHAAN OTOMOTIF YANG TERDAFTAR DI BURSA EFEK INDONESIA
}

\author{
MUHAMMAD JALIL \\ Universitas Islam Indragiri \\ Email : m.jali110000@gmail.com
}

\begin{abstract}
ABTRACT
This study aims to examine the effect of accounting profit and cash flow on stock trading volume in Automotive Companies Listed on the Indonesia Stock Exchange (IDX). This study uses secondary data with a sample of 12 Automotive Companies Listed on the Indonesia Stock Exchange (IDX) Indonesia in the period 2016 to 2018. The data analysis technique used is the classical assumption test and hypothesis testing using multiple linear regression. The results showed that partially accounting profit and cash flow had a significant effect on stock trading volume. Simultaneous test results show that accounting profit and cash flow together have a significant effect on stock trading volume. The value of the coefficient of determination in this study is 0.823 or $82.3 \%$, which means that $82.3 \%$ of accounting profit and cash flow variables affect stock trading volume. While $17.7 \%$ is explained or influenced by other variables not examined in this study
\end{abstract}

Keywords: Accounting Profit, Cash Flow, Stock Trading Volume

\section{ABSTRAK}

Penelitian ini bertujuan menguji pengaruh laba akuntansi dan arus kas terhadap volume perdagangan saham pada Perusahaan Otomotif yang terdaftar di Bursa Efek Indonesia (BEI). Penelitian ini menggunakan data sekunder dengan jumlah sampel sebanyak 12 perusahaan Otomotif yang terdaftar di Bursa Efek Indonesia (BEI) Indonesia dalam periode tahun 2016 sampai 2018. Teknik anlisis data yang digunakan yaitu uji asumsi klasik dan uji hipotesis dengan menggunakan regresi linear berganda. Hasil penelitian menunjukan bahwa secara parsial laba akuntansi dan arus kas berpengaruh secara signifikan terhadap volume perdagangan saham. Hasil uji simultan menunjukkan bahwa laba akuntansi dan arus kas secara bersama-sama berpengaruh signifikan terhadap volume perdagangan saham. Nilai koefisien determinasi dalam penelitian ini adalah sebesar 0,823 atau sebesar 82,3\% yang berarti bahwa 82,3\% variabel laba akuntansi dan arus kas mempngaruhi volume perdagangan saham. Sedangkan $17,7 \%$ dijelaskan atau dipengaruhi oleh variabel lain yang tidak diteliti dalam penelitian ini.

Kata kunci: Laba Akuntansi, Arus Kas, Volume Perdaganggan Saham.

\section{PENDAHULAUAN}

\subsection{Latar Belakang Masalah}

Seiring dengan perkembangan pasar modal, kebutuhan akan informasi yang relevan dalam pengambilan keputusan oleh investor juga semakin meningkat, kegiatan pasar modal tidak akan terlepas dari tersedianya berbagai macam informasi tentang perusahaan. Informasi bagi para pelaku atau investor di pasar bursa tersebut akan mempengaruhi berbagai macam keputusan yang akan diambil yang berakibat pada perubahan atau fluktuasi baik harga maupun kuantitas saham yang diperdagangkan. Perkembangan volume perdagangan saham di pasar modal merupakan suatu indikasi penting untuk mempelajari tingkah laku pasar, yaitu investor (Rohman, 2005)

Investor dalam melakukan transaksi di pasar modal biasanya mereka akan mendasarkan keputusannya pada berbagai informasi yang dimilikinya, baik informasi yang tersedia di publik maupun informasi pribadi. Salah satu informasi yang tersedia di publik adalah laporan keuangan tahunan perusahaan yang telah diaudit yang komponennya meliputi : 1) neraca, 2) laba-rugi, 3) perubahan ekuitas, 4) arus kas dan 5) catatan atas laporan keuangan. Menurut Bangun (2014) informasi-informasi tersebut akan memiliki makna atau nilai bagi para investor jika keberadaan informasi tersebut menyebabkannya melakukan transaksi di pasar modal, dimana transaksi ini salah satunya tercemin melalui perubahan volume perdagangan saham. Volume perdagangan saham itu sendiri merupakan indeks yang baik untuk mengukur tingkat kinerja perusahaan, dimana volume perdagangan saham terpengaruh langsung dengan cepat oleh informasi yang tersedia. Informasi ini dibutuhkan oleh berbagai pihak terutama para investor. Informasi yang dikeluarkan akan menimbulkan reaksi pasar.

Salah satu informasi dari laporan keuangan yang dipublikasikan adalah pengumuman mengenai informasi laba akuntansi dan laporan arus kas. Informasi laba akuntansi menurut Suwardjono (2014) adalah selisih pengukuran pendapatan dan biaya secara akrual. Informasi laba akuntansi sering digunakan oleh para investor untuk memperkirakan nilai suatu saham. Informasi laba akuntansi memberikan sinyal bagi investor mengenai nilai sesungguhnya dari suatu saham. Jika informasi laba akuntansi suatu perusahaan memberikan sinyal yang positif atau mengalami peningkatan maka para investor akan mendasarkan keputusan 
investasinya pada laba akuntansi, minat investor terhadap saham perusahaan akan berpengaruh terhadap permintaan saham yang diperdagangkan, sehingga akan terjadi reaksi terhadap volume perdagangan saham perusahaan.

Faktor lain yang menjadi pertimbangan oleh investor dalam menilai kinerja perusahaan adalah laporan arus kas. Laporan arus kas disebut juga sebagai laporan perubahan finansial atau laporan aliran dana perusahaan (Tandelilin, 2011). Laporan arus kas adalah laporan yang memberikan informasi yang relevan tentang penerimaan dan pengeluaran kas dari suatu perusahaan pada suatu periode tertentu. Laporan arus kas dinilai banyak memberikan informasi tentang kemampuan perusahaan dalam mendapatkan laba dan kondisi likuidasi perusahaan dalam mendapatkan laba dan kondisi likuidasi perusahaan pada suatu periode tertentu dengan mengklasifikasikan transaksi pada aktivitas operasi, pembiayaan dan investasi (Harahap, 2011).

Beberapa bukti empiris tentang informasi laba akuntansi dan laporan arus kas terhadap volume perdagangan saham. Penelitian Susilowati dan Sinaga (2019); Harrid dan Fitra (2017) yang menunjukan bahwa laba akuntansi dan arus kas berpengaruh terhadap volume pedagangan saham. Menurut Susilowati dan Sinaga (2019) pengumuman informasi akuntansi khususnya informasi laba bersih akan memberikan sinyal bahwa perusahaan mempunyai prospek yang baik di masa yang akan datang dan mengestimasi kemampuan perusahaan dalam menghasilkan laba di masa yang akan datang. Kemampuan perusahaan dalam menghasilkan kas yang tinggi akan menyebabkan direspon positif oleh investor sehingga menyebabkan volume perdagangan saham perusahaan semakin meningkat. Hal ini berarti setiap terjadi peningkatan laba akuntansi dan baiknya informasi terkait dengan arus kasa maka akan diikuti dengan kenaikan harga saham dan perputaran saham meningkat

Hal ini berbeda dengan penelitian yang dilakukan Azhar L, dkk (2015) dimana peningkatan laba akuntansi ternyata tidak diikuti dengan peningkatan volume perdagangan saham. Menurut Triyono dan Jogiyanto (2000) dalam Azhar L, dkk (2015) laba akuntansi tidak memiliki kandungan informasi baru yang dapat merubah pandangan investor terhadap perusahaan, sehingga konsekuansinya informasi tersebut tidak bisa meningkatkan atau menurunkan gairah pasar untuk melakukan transaksi saham perusahaan manufaktur. Sedangkan penelitian Bastomi (2014) menunjukan bahwa arus kas investasi berpengaruh terhadap volume perdagangan. Namun, arus kas operasi, arus kas pendanaan, dan total arus kas tidak berpengaruh. Hal ini menunjukkan bahwa tidak semua arus kas informasi dapat digunakan oleh investor sebagai dasar pengambilan keputusan investasi

Informasi laba akuntansi dan arus kas yang terjadi dapat memberikan sinyal bagi investor mengenai nilai sesungguhnya dari suatu saham dan peningkatan laba akuntansi dan arus kas akan diikuti dengan kenaikan harga saham. Maka dari itu peneliti bermaksud untuk melakukan penelitian lebih lanjut mengenai pengaruh laba akuntansi dan arus kas terhadap volume perdagangan saham pada perusahaan otomotif yang terdaftar di Bursa Efek Indonesia (BEI).

\subsection{Perumusan Masalah}

Berdasarkan latar belakang masalah diatas maka dibuat perumusan masalah sebagai berikut:

1. Apakah laba akuntansi berpengaruh terhadap volume perdagangan saham pada perusahaan Otomotif yang terdaftar di Bursa Efek Indonesia?

2. Apakah arus kas berpengaruh terhadap volume perdagangan saham pada perusahaan Otomotif yang terdaftar di Bursa Efek Indonesia?

3. Apakah laba akuntansi dan arus kas berpengaruh secara simultan terhadap volume perdagangan saham pada perusahaan Otomotif yang terdaftar di Bursa Efek Indonesia?

\section{TINJAUAN PUSTAKA}

\subsection{Laba Akuntansi}

Untuk menentukan keputusan investasinya, calon investor perlu menilai kemampuan perusahaan untuk memperoleh laba bersih sehingga diharapkan perusahaan dapat memberikan tingkat pengembalian yang tinggi. Laba bersih (net income atau earning) dapat dijadikan sebagai suatu ukuran kinerja perusahaan selama satu periode tertentu (Maulidasari, 2019)

Laba merupakan ukuran kinerja suatu periode, oleh karena itu tidak termasuk pos-pos yang luar biasa pada periode tersebut atau pos-pos yang pada dasarnya mempengaruhi periode lainnya. Informasi mengenai laba ini sangat menjadi perhatian investor, kreditur dan pihak lain yang bermaksud menilai prospek arus kas masuk bersih suatu perusahaan. Informasi mengenai laba ini dapat dilihat pada laporan keuangan (Lukito dan Chandra, 2016). Laba akuntansi yang tercermin dalam laporan keuangan mengandung informasi yang akan menimbulkan perubahan reaksi investor dalam pengambilan keputusan. Laba akuntansi adalah laba bersih yang diperoleh setelah dikurangi biaya-biaya operasional perusahaan (Abbas, 2019)

\subsection{Arus Kas}

Laporan arus kas adalah laporan keuangan dasar yang melaporkan kas yang diterima dan perubahannya dari kas yang dihasilkan dari operasi, investasi dan aset pembiayaan bisnis selama periode tertentu. Menurut PSAK No.2, definisi laporan arus kas adalah pernyataan yang memberikan informasi historis tentang perubahan kas dan setara kas suatu perusahaan melalui laporan arus kas yang 
mengklasifikasikan arus kas berdasarkan aktivitas operasi, aktivitas investasi, dan aktivitas pendanaan selama suatu periode akuntansi. Laporan arus kas dianggap memberikan banyak informasi tentang kemampuan perusahaan untuk memperoleh laba dan likuiditas di masa depan (Utomo dan Pamungkas, 2018)

Informasi tentang arus kas suatu perusahaan berguna bagi para pengguna laporan keuangan sebagai dasar untuk menilai kemampuan perusahaan dalam menghasilkan kas dan setara kas serta menilai kebutuhan perusahaan untuk menggunakan arus kas tersebut. Tujuan informasi arus kas adalah memberi informasi historis mengenai perubahan kas dan setara kas dari suatu perusahaan melalui laporan arus kas yang mengklasifikasikan arus kas berdasarkan aktivitas operasi, investasi, dan pendanaan selama suatu periode akuntansi (Adiliawan, 2010)

Arus kas operasi merupakan indikator operasinya yang menentukan apakah perusahaan dapat menghasilkan uang tunai yang dapat digunakan untuk membayar kembali pinjaman, menjaga kemampuan operasi perusahaan, membayar dividen. Secara teori, semakin tinggi arus kas akan semakin manrik makan investor. Arus kas investasi adalah arus kas yang mencerminkan penerimaan dan pengeluaran kas sehubungan dengan sumber daya yang bertujuan untuk menghasilkan pendapatan dan arus kas di masa yang akan datang, sehingga peningkatan investasi berkaitan erat dengan arus kas di masa yang akan datang jika dapat menarik investor. Arus kas pembiayaan adalah arus kas yang diperoleh untuk operasi pinjaman dan pembayaran utang, perolehan sumber daya yang dimiliki oleh pemilik perusahaan, serta imbalan atas investasi (Abbas, 2019)

\subsection{Volume Perdagangan saham}

Menurut Sosilowati dan Sinaga (2019) harga saham merupakan hasil dari interaksi permintaan dan penawaran saham di bursa. Banyaknya permintaan dan penawaran saham tersebut digambarkan pada volume perdagangan saham. Menurut Bustomi (2014) bahwa volume perdagangan saham (Trading Volume Activity) dapat digunakan sebagai salah satu indikator untuk melihat reaksi investor atas aktivitas volume perdagangan. Volume perdagangan saham merupakan besarnya jumlah perbandingan antara saham yang diperdagangkan dengan jumlah lembar saham yang beredar pada waktu tertentu akibat dari transaksi di pasar modal

Dalam membuat keputusan investasinya, seorang investor yang rasional akan mempertimbangkan risiko dan tingkat keuntungan yang diharapkan. Untuk itu investor seharusnya melakukan analisis sebelum menentukan saham yang akan mereka beli. Dalam melakukan analisis, investor membutuhkan informasi. Adanya informasi yang dipublikasikan akan merubah keyakinan para investor yang dapat dilihat dari reaksi pasar. Salah satu reaksi pasar tersebut adalah reaksi volume perdagangan saham. Menurut Maulidasari (2019) kegiatan perdagangan saham tidak berbeda dengan perdagangan pada umumnya yang melibatkan penjual dan pembeli. Dari adanya perdagangan saham yang terjadi maka akan menghasilkan volume perdagangan saham. Hal ini menyebabkan jumlah transaksi saham atau volume saham yang diperjualbelikan dapat berubah-ubah setiap hari

\subsection{Kerangka Pemikiran}

Gambar 2.1

Kerangka Pemikiran

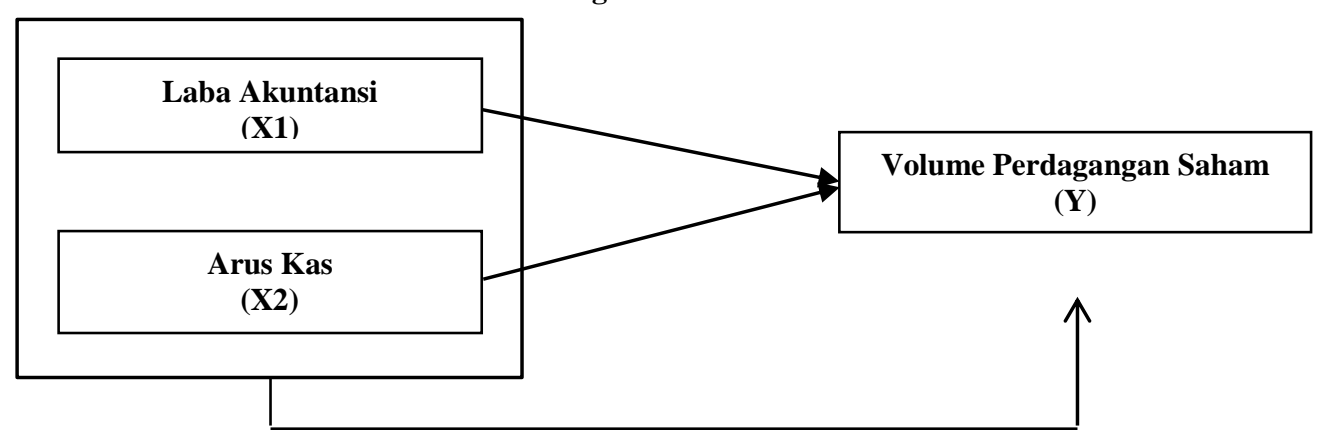

Variabel Independen

Variabel Dependen

\subsection{Hipotesis Penelitian}

$\mathrm{H}_{1}=$ Laba akuntansi berpengaruh terhadap volume perdagangan saham pada perusahaan otomotif yang terdaftar di Bursa Efek Indonesia.

$\mathrm{H}_{2}=$ Arus kas berpengaruh terhadap volume perdagangan saham pada perusahaan otomotif yang terdaftar di Bursa Efek Indonesia

$\mathrm{H}_{3}=$ Laba akuntansi dan Arus kas secara simultan berpengaruh terhadap volume perdagangan saham pada perusahaan otomotif yang terdaftar di Bursa Efek Indonesia. 


\section{METODE PENELITIAN}

\subsection{Rancangan Penelitan}

Jenis penelitian dalam penelitian ini adalah kausal komparatif (Causal comparative research) yang merupakan tipe penelitian dengan karakteristik masalah berupa hubungan sebab-akibat antara dua variabel atau lebih (Sugiyono, 2014). Penelitian ini termasuk penelitian kuantitatif dimana menurut Arikunto (2006) penelitian keuantitatif banyak menggunakan angka mulai dari pengumpulan data, penafsiran terhadap data, serta penampilan dari hasil penelitian.

\subsection{Tempat dan Waktu Penelitian}

Penelitian ini dilakukan pada Bursa Efek Indonesia (BEI), dengan memperoleh data keuangan yang dibutuhkan melalui internet dan Indonesian Market Capital Directori (ICMD), yaitu berupa laporan keuangan perusahaan yang tergolong otomotif yang terdaftar di Bursa Efek Indonesia selama periode 20162018 .

\subsection{Populasi Dan Sampel}

Populasi dalam penelitian ini adalah seluruh perusahaan manufaktur yang terdaftar di Bursa Efek Indonesia (BEI) tahun 2016-2018 dengan sub sektor pada perusahaan otomotif sebanyak 12 perusahaan. Teknik penarikan sampel dengan menggunakan metode purposive sampling yang merupakan suatu metode pengambilan sampel yang disesuaikan dengan kriteria-kriteria tertentu. Adapun kriteria dalam dalam sampel penelitian ini adalah sebagai berikut:

1. Perusahaan otomotif yang terdaftar di Bursa Efek Indonesia berdasarkan dari tahun 2016-2018

2. Perusahaan otomotif yang mempublikasikan laporan keuangan, laba akuntansi secara lengkap untuk tahun 2016-2018

3. Perusahaan otomotif yang mempublikasikan laporan arus kas secara lengkap untuk tahun 2016-2018

4. Selama periode penelitian, perusahaan otomotif tidak mengalami rugi

5. Laba perusahaan otomotif mengalami keuntungan sebesar 3 trililun,- sampai dengan 5 trililun dari tahun 2016-2018

Tabel 3.1

Perhitungan Perusahaan yang Menjadi Sampel

\begin{tabular}{|c|l|c|}
\hline No & \multicolumn{1}{|c|}{ Keterangan } & Jumlah \\
\hline 1 & $\begin{array}{l}\text { Perusahaan otomotif yang terdaftar di Bursa Efek Indonesia berdasarkan dari } \\
\text { tahun 2016-2018. }\end{array}$ & 13 \\
\hline 2 & $\begin{array}{l}\text { Perusahaan otomotif yang mempublikasikan laporan keuangan, laba } \\
\text { akuntansi secara lengkap utuk tahun 2015-2017. }\end{array}$ & 13 \\
\hline 3 & $\begin{array}{l}\text { Perusahaan otomotif yang mempublikasikan laporan arus kas secara lengkap } \\
\text { untuk tahun 2016-2018. }\end{array}$ & 13 \\
\hline 4 & $\begin{array}{l}\text { Selama periode penelitian, perusahaan otomotif tidak mengalami rugi mulai } \\
\text { tahun 2016-2018 }\end{array}$ & 13 \\
\hline 5 & $\begin{array}{l}\text { Laba perusahaan otomotif mengalami keuntungan sebesar 3 trililun,- sampai } \\
\text { dengan 5 trililun dari tahun 2016-2018 }\end{array}$ & 12 \\
\hline & Jumlah Sampel & 12 \\
\hline
\end{tabular}

Sumber: Data diolah peneliti (2020)

\subsection{Prosedur Pengumpulan Data}

Data dalam penelitian ini adalah data sekunder yang diperoleh dari Bursa Efek Indonesia. Data sekunder adalah data yang diperoleh dari media. Data sekunder umumnya berupa bukti, catatan atau laporan historis yang telah tersusun yang dipublikasikan dan yang tidak dipublikasikan. Data yang digunakan dalam penelitian ini adalah data yang berupa laporan keuangan seluruh perusahaan manufaktur terdaftar di BEI, yang data tersebut akan diperoleh dari ICMD.

\subsection{Definisi Operasional dan Pengukuran Variabel}

1. Laba Akuntansi $\left(\mathbf{X}_{1}\right)$

Laba bersih yang digunakan adalah laba bersih sebelum extraordinary items dan discounted operations. Alasan mengeluarkan kedua item tersebut adalah untuk menghilangkan elemen yang mungkin menyebabkan pertumbuhan laba meningkat dalam satu periode yang tidak akan timbul dalam periode lainnya. Aprinta (2015), menjelaskan rumus laba akuntansi sebagai berikut :

Laba per lembar saham $=$

Laba akuntansi $\mathrm{t}$

Jumlah lembar saham yang beredar $\mathrm{t}$

\section{2. $\quad$ Arus Kas $\left(\mathbf{X}_{2}\right)$}

Arus kas adalah memberi informasi historis mengenai perubahan kas dan setara kas dari suatu perusahaan melalui laporan arus kas. Dalam penelitian ini yang menjadi variabel independan adalah arus kas 
operasi. Arus operasi adalah arus kas yang berasal dari aktivitas penghasilan utama pendapatan perusahaan. Aprinta (2015) menjelaskan rumus arus kas operasi sebagai berikut :

Arus Kas Operasi $=$ Total arus Kas Akhir Tahun - Total Arus Kas Awal Tahun

\section{Volume Perdagangan Saham (Y)}

Volume perdagangan saham merupakan variabel dependen (Y), tinggi rendahnya volume perdagangan saham yang dipengaruhi oleh banyak faktor yaitu faktor mikro dan mikro, namun dalam penelitian ini menekankan pada analisa pengaruh volume perdagangan saham secara mikro yang dilihat dari kinerja perusahaan dalam menghasilkan dan menggunakan kas. Menurut Aprinta (2015) volume perdagangan dihitung menggunakan rumus:

$\sum$ saham perusahaan i yang diperdagangkan pada waktu $\mathrm{t}$

$\mathrm{TV} \mathrm{Ai}, \mathrm{t}=$

$$
\sum \text { saham perusahaan i yang beredar (listing)t }
$$

\subsection{Teknik Analisis Data}

Pengujian hipotesa menggunakan teknik uji regresi berganda yang terlebih dahulu dilakukan uji asumsi klasik. Uji asumsi klasik bertujuan untuk mengetahui data tersebut normal atau tidaknya.

\section{HASIL PENELITIAN DAN PEMBAHASAN \\ 4.1 Hasil Penelitian}

\section{Statistik Deskriptif}

Statistik deskripsif memberikan gambaran mengenai nilai, mean, median, standar deviasi, variance, range, minimum, dan maksimum. Statistik deskriptif hanya berhubungan dengan hal yang menguraikan atau memberikan keterangan-keterangan mengenai suatu data atau keadaan (fenomena). Berikut ini analisis deskriptif dalam penelitian ini adalah:

Tabel 4.1

Descriptive Statistics

\begin{tabular}{|l|r|r|r|r|r|}
\hline & N & Minimum & Maximum & \multicolumn{1}{|c|}{ Mean } & Std. Deviation \\
\hline Laba Akuntansi & 36 & 1.04 & 975.00 & 471.1400 & 267.32445 \\
Arus Kas & 36 & 19.41 & 175.32 & 42.8227 & 43.61193 \\
Volume Perdagangan Saham & 36 & 79.01 & 491.97 & 159.1616 & 102.44680 \\
Valid N (listwise) & 36 & & & \\
\hline
\end{tabular}

Sumber: Data Olahan SPSS Versi 22, 2020

Dari tabel 4.1 dapat dilihat jumlah data $(\mathrm{N})$ yang valid 36, nilai minimum dari data laba akuntansi adalah 1,04, nilai minimum dari data arus kas adalah 19,41, Nilai minimum dari volume perdagangan saham adalah 79,01. Nilai maksimum dari data laba akuntansi adalah 975.00. Nilai maksimum dari data arus kas adalah 175,32. Nilai maksimum dari data volume perdagangan saham adalah 491,97. Nilai rata-rata (mean) laba akuntansi 471,1400. Nilai rata-rata (mean) arus kas 42,8227. Nilai rata-rata (mean) volume perdagangan saham adalah 159,1616. Deviasi standar dari variabel laba akunatansi adalah 267,32445, variabel arus kas adalah 43,61193, dan volume perdagangan adalah 102,44680.

\section{Uji Asumsi Klasik}

a. Uji Normalitas

Uji normalitas data bertujuan apakah dalam model regresi, variabel bebas dan variabel terikat memiliki distribusi normal dan tidak. Pengujian digunakan untuk menguji normalitas residual suatu model regresi adalah menggunakan uji statistik non parametric KS (Kolmogrov -Smirnov). Berikut ini grafik dari uji normalitas yaitu:

\section{Gambar : 4.1}

\section{Normal P-P Plopt Regression Standardized Residual}

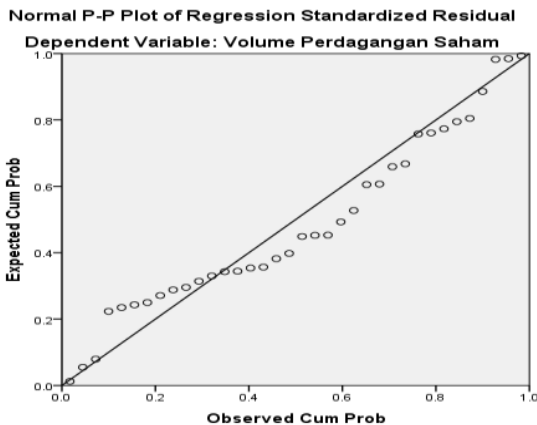

Sumber: Data Olahan SPSS Versi 22, 2020

Muhammad Jalil, Pengaruh Laba Akuntansi Dan Arus Kas Terhadap Volume Perdagangan Saham Pada Perusahaan Otomotif Yang Terdaftar Di Bursa Efek Indonesia 
Dari output kurva Normal P-Plot diatas terlihat normal, dimana dari variabel independen yaitu (laba akuntansi dan arus kas) dan variabel dependen Y (volume perdagangan saham) menjelaskan bahwa titik-titik menyebar mendekati garis diagonal. Titik-titik data menyebar dan mengikuti arah garis diagonal, walaupun masih ada yang menjauhi garis diagonal sedikit sehingga model regresi dalam penelitian ini memiliki distribusi data normal atau mendekati normal.

b. Uji Autokorelasi

Uji autokolerasi bertujuan untuk mengetahui ada tidaknya kolerasi antara variabel pengganggu pada periode tertentu dengan variabel pengganggu sebelumnya. Cara menguji autokolerasi adalah dengan melihat model regresi linier sederhana terbebas dari autokolerasi apabila nilai Durbin Watson berada dibawah angka 2 .

Tabel 4.2

Hasil Uji Autokorelasi Model Summary ${ }^{\mathrm{b}}$

\begin{tabular}{|l|r|r|r|r|r|}
\hline Model & \multicolumn{1}{|c|}{$\mathrm{R}$} & R Square & $\begin{array}{c}\text { Adjusted R } \\
\text { Square }\end{array}$ & $\begin{array}{c}\text { Std. Error of the } \\
\text { Estimate }\end{array}$ & $\begin{array}{c}\text { Durbin- } \\
\text { Watson }\end{array}$ \\
\hline 1 & $.851^{\mathrm{a}}$ & .823 & .870 & 9.63909 & 2.160 \\
\hline
\end{tabular}

a. Predictors: (Constant), Arus Kas, Laba Akuntansi

b. Dependent Variable: Volume Perdagangan Saham

Sumber: Data Olahan SPSS Versi 22, 2020

Dari tabel 4.2 dapat dilihat nilai Durbin - Watson sebesar 2,160 nilai ini terletak pada interval 1,55 $<2,160<2,46$, dengan demikian dapat disimpulkan bahwa dalam data pengamatan tidak ada autokorelasi.

c. Uji Heterokendastisitas

Uji heterokedastisitas bertujuan untuk menguji apakah dalam model regresi terjadi ketidaksamaan variance dari residual satu pengamatan ke pengamatan lain. Berikut ini grafik uji heterokendastisitas yaitu:

\section{Gambar 4.2}

\section{Grafik Uji Heterokedastisitas}

Scatterplo

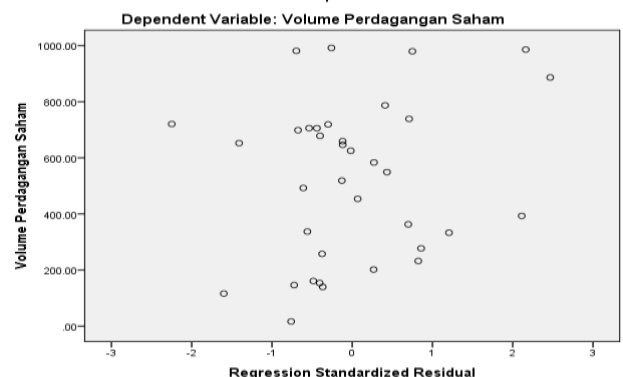

Sumber: Data Olahan SPSS 22, 2020

Berdasarkan gambar Scatter-Plot tersebut dapat diambil kesimpulan bahwa tidak ada pola yang jelas, serta titik-titiknya sebagian menyebar. Dengan demikian maka semua variabel independen terbebas dari pengujian asumsi klasik.

d. Uji Multilinearitas

Uji ini dilakukan untuk ada tidaknya kolerasi yang besar diantara variabel bebas. Hasil pengujian multilinearitas dapat dilihat pada tabel 4.3 yaitu:

Tabel 4.3

Hasil Uji Multikolinearitas Coefficients $^{\mathrm{a}}$

\begin{tabular}{|ll|r|r|}
\hline \multirow{2}{*}{ Model } & \multicolumn{2}{|c|}{ Collinearity Statistics } \\
\cline { 3 - 4 } & & Tolerance & \multicolumn{1}{c|}{ VIF } \\
\hline 1 & Laba Akuntansi & .916 & 1.091 \\
& Arus Kas & .916 & 1.091 \\
\hline
\end{tabular}

a. Dependent Variable: Volume Perdagangan Saham Sumber: Data Olahan SPSS 22, 2020

Hasil pengujian multilinearitas dapat dilihat pada tabel di atas menujukkan bahwa variabel bebas yaitu: laba akuntansi sebesar 1,091, dan arus kas sebesar 1,091 memilki angka variance inflaciton factor (VIF) dibawah angka 10. Dengan demikian disimpulkan persamaan regresi yang dapat dipakai sebagai model analisis tidak terdapat persoalan multilinearitas. 
3. Uji Hipotesis

a. Uji Regresi Berganda

Analisis regresi berganda bertujuan untuk mengetahui ada tidaknya pengaruh variabel independen yaitu (laba akuntansi dan arus kas) terhadap variabel dependen (volume perdagangan saham). Berikut ini adalah hasil analisis regresi berganda yaitu:

Tabel 4.4

Hasil Uji Regresi Berganda

Coefficients $^{\mathrm{a}}$

\begin{tabular}{|c|c|c|c|c|c|c|c|}
\hline \multirow[b]{2}{*}{ Model } & \multicolumn{2}{|c|}{$\begin{array}{l}\text { Unstandardized } \\
\text { Coefficients }\end{array}$} & \multirow{2}{*}{$\begin{array}{c}\begin{array}{c}\text { Standardized } \\
\text { Coefficients }\end{array} \\
\text { Beta }\end{array}$} & \multirow{2}{*}{$\mathrm{T}$} & \multirow{2}{*}{ Sig. } & \multicolumn{2}{|c|}{$\begin{array}{l}95.0 \% \text { Confidence Interval } \\
\text { for B } \\
\end{array}$} \\
\hline & B & Std. Error & & & & $\begin{array}{l}\text { Lower } \\
\text { Bound }\end{array}$ & $\begin{array}{l}\text { Upper } \\
\text { Bound }\end{array}$ \\
\hline (Constant) & 10.317 & 16.911 & & 5.932 & .000 & 65.911 & 134.724 \\
\hline Laba Akuntansi & 1.037 & .206 & 1.196 & 4.153 & .002 & 1.005 & 1.019 \\
\hline Arus Kas & 1.607 & .116 & 1.239 & 3.405 & .006 & 1.451 & 2.464 \\
\hline
\end{tabular}

a. Dependent Variable: Volume Perdagangan Saham

Sumber: Data Olahan SPSS Versi 22, 2020 berikut:

Dari tabel 4.4 uji regresi berganda diatas maka diperoleh persamaan regresi berganda sebagai

$$
Y=10.317+1.037 X_{1}+1.607 X_{2}+\varepsilon
$$

b. Uji Parsial (Uji t)

Untuk melakukan pengujian variabel independen (laba akuntansi dan arus kas) secara parsial terhadap variabel dependen (volume perdagangan saham) maka pengujian yang dilakukan adalah uji t, Uji ini digunakan untuk mengetahui signifikan atau tidaknya pengaruh antara variabel independen terhadap variabel dependen secara sendiri-sendiri. Adapun hasil uji parsial yaitu sebagai berikut:

1. Variabel laba akuntansi memiliki $t_{\text {hitung }}$ sebesar 4,153 sedangkan $t_{\text {tabel }}$ sebesar 1,688 sehingga $t_{\text {hitung }}<t_{\text {tabel }}$ dengan signifikan untuk variabel laba akuntansi sebesar 0,002 lebih kecil daripada taraf signifikan 0,05.

Maka $\mathrm{H}_{1}$ diterima sehingga dapat disimpulkan bahwa secara parsial laba akuntansi berpengaruh positif secara signifikan terhadap volume perdagangan saham.

2. Variabel arus kas memiliki $t_{\text {hitung }}$ sebesar 3,405 sedangkan $t_{\text {tabel }}$ sebesar1,688 sehingga $t_{\text {hitung }}>t_{\text {tabel }}$ dengan signifikansi sebesar 0,006 yang artinya lebih kecil dari taraf nyata signifikansi sebesar 0.05 . $\mathrm{Maka}_{2}$ diterima. Sehingga dapat disimpulkan bahwa arus kas $\left(\mathrm{X}_{2}\right)$ secara parsial berpengaruh positif secara signifikan terhadap volume perdagangan saham.

c. Hasil Uji F (Uji Simultan)

Uji simultan (uji F) bertujuan untuk mengetahui pengaruh variabel independen secara bersama sama terhadap variabel dependen dengan melihat nilai signifikan F. Untuk mengetahui hasil uji $\mathrm{F}$ dapat dilihat pada tabel sebagai berikut:

Tabel 4.5

Tabel uji Hipotesis secara simultan ANOVA $^{\mathrm{a}}$

\begin{tabular}{|ll|r|r|r|r|r|}
\hline Model & & Sum of Squares & \multicolumn{1}{c|}{ Df } & Mean Square & F & \multicolumn{1}{c|}{ Sig. } \\
\hline 1 & Regression & 118.376 & 3 & 394.459 & 21.449 & $.000^{b}$ \\
& Residual & 7.581 & 42 & .180 & & \\
& Total & 119.957 & 45 & & & \\
\hline
\end{tabular}

a. Dependent Variable: Volume Perdangan Saham

Sumber: Data Olahan SPSS Versi 22, 2020

Dari tabel 4.5 maka dapat diketahui hasil uji Anova (analysis of varians) atau uji F, menunjukkan bahwa nilai $F_{\text {hitung }}$ sebesar 21,449 sedangkan $F_{\text {tabel }}$ sebesar 3,260 dengan signifikan $\alpha=0,05$ sehingga $F_{\text {hitung }}>$ $F_{\text {tabel. }}$ Tingkat signifikan sebesar 0,000 lebih kecil dari taraf yang ditentukan $\alpha=0,05$ nilai mengindikasikan bahwa laba akuntansi $\left(\mathrm{X}_{1}\right)$ dan arus kas $\left(\mathrm{X}_{2}\right)$ secara bersama-sama berpengaruh positif dan signifikan terhadap volume perdagangan saham sehingga $\mathrm{H}_{3}$ diterima.

\section{d. Hasil Uji Determinasi}

Koefisien determinasi $\left(\mathrm{R}^{2}\right)$ berguna untuk mengukur seberapa besar peran variabel independen (laba akuntansi dan arus kas) secara bersama-sama menjelaskan perubahan yang terjadi pada variabel dependen (volume perdagangan saham). 
Tabel 4.6

Hasil uji Koefisien determinasi Model Summary

\begin{tabular}{|l|r|r|r|c|}
\hline Model & R & R Square & \multicolumn{1}{c|}{$\begin{array}{c}\text { Adjusted R } \\
\text { Square }\end{array}$} & $\begin{array}{c}\text { Std. Error of the } \\
\text { Estimate }\end{array}$ \\
\hline 1 & $.851^{\mathrm{a}}$ & .823 & .870 & 9.63909 \\
\hline
\end{tabular}

a. Predictors: (Constant), Arus Kas, Laba Akuntansi

Sumber: Data Olahan SPSS Versi 22, 2020

Tabel 4.6 diatas diketahui bahwa koefisien determinasi ( $R$ Square) sebesar 0,823 atau sebesar $82,3 \%$. Hal ini berarti $82,3 \%$ variabel laba akuntansi dan arus kas mempngaruhi volume perdagangan saham. Sedangkan $17,7 \%$ dijelaskan atau dipengaruhi oleh variabel lain yang tidak diteliti dalam penelitian ini seperti auditor internal, komposisi dewan direksi, dan kepemilikan terkonsentras

\subsection{Pembahasan}

\section{Pengaruh Laba Akuntansi Terhadap Volume Perdagangan Saham}

Berdasarkan hasil uji parsial variabel laba akuntansi $\left(\mathrm{X}_{1}\right)$ memiliki $t_{\text {hitung }}$ sebesar 4,153 sedangkan $\mathrm{t}_{\text {tabel }}$ sebesar 1,688 sehingga $\mathrm{t}_{\text {hitung }}<\mathrm{t}_{\text {tabel }}$ dengan signifikan untuk variabel laba akuntansi sebesar 0,002 lebih kecil daripada taraf signifikan 0,05 . Maka $\mathrm{H}_{1}$ diterima sehingga dapat disimpulkan bahwa secara parsial laba akuntansi $\left(X_{1}\right)$ berpengaruh secara signifikan terhadap volume perdagangan saham hal ini dikarenakan semakin meningkat laba akuntansi maka harga saham akan semakin meningkat pula begitu juga dengan volume perdagangan saham. Dengan demikian investor akan tertarik untuk membeli saham perusahan yang meraih laba, karena investor menganggap perusahaan memiliki operasional yang baik dan memiliki prospek meraih keuntungan di masa yang akan datang sehingga volume perdagangan saham juga akan meningkat.

Penelitian ini sejalan dengan penelitian Aprinta (2015) dimana laba akuntansi berpengaruh terhadap volume perdagangan saham. Harga saham cenderung naik apabila laba yang dilaporkan lebih besar dari laba harapan, dan sebaliknya harga saham cenderung turun apabila laba yang dilaporkan lebih kecil dari laba harapan. Apabila harga saham naik maka volume perdagangan saham akan mengalami peningkatan dan investor akan tertarik untuk membeli saham perusahan yang meraih laba, karena investor menganggap perusahaan memiliki operasional yang baik dan memiliki prospek meraih keuntungan di masa yang akan dating sehingga volume perdagangan saham juga akan meningkat.

Hasil penelitian ini tidak sejalan dengan penelitian yang dilakukan Ditha (2016) dimana laba akuntansi tidak mempengaruhi volume perdagangan saham. Hal ini dikarenakan komponen yang sangat diperhatikan pada laporan laba rugi oleh investor adalah laba bersih atau disebut laba akuntansi. Laba bersih atau laba akuntansi berguna bagi investor untuk memprediksi imbalan investasi yang akan diterimanya apabila investor berinvestasi di perusahaan dan menafsirkan risiko dalam investasi.

\section{Pengaruh Arus Kas Terhadap Volume Perdagangan Saham}

Berdasarkan hasil uji persial variabel arus kas memiliki $t_{\text {hitung }}$ sebesar 3,405 sedangkan $t_{\text {tabel }}$ sebesar1,688 sehingga $t_{\text {hitung }}>t_{\text {tabel }}$ dengan signifikansi sebesar 0,006 yang artinya lebih kecil dari taraf nyata signifikansi sebesar 0,05 . Maka $\mathrm{H}_{2}$ diterima sehingga dapat disimpulkan arus kas $\left(\mathrm{X}_{2}\right)$ secara parsial berpengaruh secara signifikan terhadap volume perdagangan saham hal ini dikarenakan arus kas dari kegiatan aktivitas operasi adalah aktivitas penghasil utama pendapatan perusahaan. Semakin tinggi kemampuan menghasilkan kas, diharapkan dapat meyakinkan investor bahwa operasi perusahaan dapat menghasilkan kas yang cukup untuk melunasi pinjaman, memelihara kemampuan operasi perusahaan, membayar dividen dan melakukan investasi baru tanpa mengandalkan pada sumber dari luar. Jumlah arus kas yang berasal dari aktivitas operasi merupakan indikator yang menentukan apakah dari operasinya, perusahaan dapat menghasilkan arus kas yang cukup untuk melunasi pinjaman, memelihara kemampuan operasi perusahaan, membayar deviden dan melakukan investasi baru tanpa mengandalkan pada sumber pendanaan dari luar. Sehingga dengan adanya peningkatan arus kas dari aktivitas operasi akan memberikan sinyal positif mengenai kinerja perusahaan di masa yang akan datang kepada investor, akibatnya investor akan membeli saham perusahaan tersebut yang pada akhirnya akan meningkatkan volume perdagangan saham.

Hasil penelitian ini sejalan dengan Susilowati dan Sinaga (2019) bahwa arus kas berpangaruh terhadap volume perdagangan saham. Menurut Susilowati dan Sinaga (2019) pengumuman informasi akuntansi khususnya informasi laba bersih akan memberikan sinyal bahwa perusahaan mempunyai prospek yang baik di masa yang akan datang dan mengestimasi kemampuan perusahaan dalam menghasilkan laba di masa yang akan datang. Kemampuan perusahaan dalam menghasilkan kas yang tinggi akan menyebabkan direspon positif oleh investor sehingga menyebabkan volume perdagangan saham perusahaan semakin meningkat. Hasil penelitian ini tidak sejalan dengan Bastomi (2014) bahwa arus kas operasi tidak berpengaruh terhadap volume perdagangan saham. Menurut Bustomi (2014) naik turunnya kas bersih yang diperoleh dari aktivitas operasi setiap tahunnya tidak dapat mempengaruhi para investor untuk berinvestasi pada perusahaan 


\section{Pengaruh Laba Akuntansi dan Arus Kas Terhadap Volume Perdagangan Saham}

Berdasarkan hasil uji simultan yang menunjukkan bahwa nilai $\mathrm{F}_{\text {hitung }}$ sebesar 21,449 sedangkan $F_{\text {tabel }}$ sebesar 3,260 dengan signifikan $\alpha=0,05$ sehingga $F_{\text {hitung }}>F_{\text {tabel. }}$. Tingkat signifikan sebesar 0,000 lebih kecil dari taraf yang ditentukan $\alpha=0,05$ nilai mengindikasikan bahwa laba akuntansi $\left(\mathrm{X}_{1}\right)$ dan arus kas $\left(\mathrm{X}_{2}\right)$ secara bersama-sama berpengaruh signifikan terhadap volume perdagangan saham sehingga $\mathrm{H}_{3}$ di terima. Hal ini dikarenakan perbedaan volume perdagangan saham antara sebelum dan sesudah tanggal publikasi laporan keuangan, serta ukuran kinerja yang menjadi fokus perhatian mereka adalah ukuran kinerja yang mampu menggambarkan kondisi ekonomi perusahaan serta prospek pertumbuhan dimasa depan dengan lebih baik sehingga akan mempengaruhi volume perdagangan saham. Perkembangan volume perdagangan saham di pasar modal merupakan suatu indikasi penting untuk mempelajari tingkah laku pasar, yaitu investor.perbedaan volume perdagangan saham antara sebelum dan sesudah tanggal publikasi laporan keuangan.

Hasil penelitian ini sejalan dengan penelitian Maulidasari (2019) dan Harrid dan Fitra (2017) bahwa laba bersih dan arus kas berpengaruh terahdap volume perdagangan saham. Menurut Maulidasari (2019) parameter kinerja perusahaan yang mendapat perhatian utama dari investor dan kreditor dari laporan keuangan adalah arus kas dan laba bersih. Pada saat dihadapkan pada dua ukuran kinerja akuntansi keuangan tersebut, investor harus yakin bahwa ukuran kinerja yang menjadi fokus perhatian mereka adalah ukuran kinerja yang mampu menggambarkan kondisi ekonomi perusahaan serta prospek pertumbuhan dimasa depan dengan lebih baik. Sehingga akan mempengaruhi volume perdagangan saham

\section{KESIMPULAN DAN SARAN}

\subsection{Kesimpulan}

Berdasarkan hasil penelitian yang sudah dilakukan maka dapat disimpulan sebagai berikut:

1. Dalam penelitian ini yang menjadi sampel penelitian adalah perusahaan otomotif yang terdaftar di Bursa Efek Indonesia dengan pertimbangan Bursa Efek Indonesia memiliki data yang lebih lengkap dan telah terorganisasi dengan baik dari tahun 2016-2018 dengan jumlah sampel penelitian 12 perusahaan.

2. Hasil penelitian menunjukan bahwa secara parsial laba akuntansi dan arus kas berpengaruh secara signifikan terhadap volume perdagangan saham hal ini dikarenakan semakin meningkat laba akuntansi maka investor tertarik terhadap perusahaan dan akan meningkatkan volume perdagangan saham. Hasil uji simultan menunjukan bahwa laba akuntansi dan arus kas secara bersama-sama berpengaruh signifikan terhadap volume perdagangan

2. Hasil koefisien determinasi ( $R$ Square) sebesar 0,823 atau sebesar 82,3\%. Hal ini berarti 82,3\% variabel laba akuntansi dan arus kas mempngaruhi volume perdagangan saham. Sedangkan 17,7\% dijelaskan atau dipengaruhi oleh variabel lain yang tidak diteliti dalam penelitian ini.

\subsection{Saran}

Berdasarkan hasil kesimpulan diatas maka penulis menyarankan sebagai berikut:

1. Bagi peneliti selanjutnya diharapkan jika membuat penelitian sejenis, maka dapat menambah jumlah sampel penelitian dan tahun penelitian agar hasil penelitian lebih akurat.

2. Adanya penambahan variabel selain laba akuntansi dan arus kas lain seperti auditor internal, komposisi dewan direksi, dan kepemilikan terkonsentrasi.

3. Penelitian selanjutnya dapat menggunakan proksi pengukuran lain terkait dengan konservatisme yang dianggap dapat menggambarkan keadaan sebenarnya dalam mengukur kinerja laporan keuangan.

\section{DAFTAR PUSTAKA}

Abbas, Dirvi Surya. 2019. Effect Of Accounting Profit, Operating Cash Flow, Investment Cash Flow, Financing Cash Flow And Net Profit Margin On Return Of Shares (On Insurance Company Listed On The Stock Exchange In 2011-2014). Universitas Muhammadiyah Tangerang

Adiliawan, Novy Budi. 2010. Pengaruh Komponen Arus Kas Dan Laba Kotor Terhadap Harga Saham (Studi Kasus Pada Perusahaan Manufaktur di Bursa Efek Indonesia). Skripsi. Universitas Diponegoro. Semarang

Afrinta, Riri. 2015. Pengaruh Laba Akuntansi, Total Arus Kas, Komponen Arus Kas, Return On Equity Terhadap Volume Perdagangan Saham Pada Perusahaan Pertambangan Yang Terdaftar Di Bursa Efek Indonesia Tahun 2010-2013. Jom FEKON Vol. 2 No. 2

Arikunto, S. 2006. Prosedur Penelitian. Jakarta: Rienika Cipta

Azhar L, Rofika dan Rohayati, Lilis. 2015. Pengaruh Informasi Arus Kas dan Laba Akuntansi terhadap Volume Perdagangan Saham pada Perusahaan Manufaktur yang Terdaftar di Bursa Efek Indonesia. Perpustakaan Universitas Riau

Bangun, Pribadi, 2014. Pengaruh Informasi Laporan Arus Kas, Laba Bersih Dan Size Perusahaan Terhadap Volume Perdagangan Saham Pada Perusahaan Manufaktur Yang Terdaftar Di Bursa Efek Indonesia (BEI). Undergraduate thesis. Universitas Negeri Medan 
Bastomi, Ahmad Yazid Al. 2014. Pengaruh Informasi Laporan Arus Kas Terhadap Volume Perdagangan Saham Pada Perusahaan Food And Beverage Yang Tercatat Di Bursa Efek Indonesia. AKUNESA Vol. 3 No. 1

Ditha, Meyvira. 2016. Pengaruh Informasi Arus Kas Dan Laba Bersih Terhadap Volume Perdagangan Saham (Studi pada Perusahaan Food and Beverages yang Terdaftar di Bursa Efek Indonesia Tahun 2012 - 2014). Diploma thesis. Universitas Andalas.

Harahap, Sofyan Syafri. 2011. Analisis Kritis atas laporan Keuangan. Edisi Pertama Cetakan ke sepuluh. Jakarta : PT Bumi Aksara.

Harrid, Fitria. 2017. Pengaruh Laba Akuntansi, Total Arus Kas dan Kebijakan Deviden terhadap Harga Saham. Skripsi. Universitas Negeri Padang.

Lukito, N dan Chandra., K. 2016. Effect Of Information On Accounting Profits And Cash Flow Components On Stock Prices Of Insurance Companies Listed In Indonesia Stock Exchange (Bei) 2008-2012 Period. Business and Entrepreneurial Review Vol.15, No.2

Maulidasari, Dini Nurul. 2020. Pengaruh Informasi Arus Kas Dan Laba Bersih Terhadap Volume Perdagangan Saham Pada Perusahaan Manufaktur Sektor Otomotif Yang Terdaftar Di BEI Periode 2009-2012. Jurnal Ilmu Manajemen Retail (JIMAT) Vol. 1 No. 1

Rohman, Abdul. 2005. Pengaruh Langsung Dan Tidak Langsung Arus Kas Dan Laba Terhadap Volume Perdagangan Saham Pada Emiten Di Bursa Efek Jakarta. Jurnal Akuntansi \& Auditing Vol. 1 No. 2

Sugiyono. 2014. Metode Penelitian Pendidikan Pendekatan Kuantitatif, Kualitatif, dan R\&D. Bandung: Alfabeta

Suwardjono. 2014. Teori Akuntansi (Perekayasaan Pelaporan Keuangan) Edisi Ketiga. Yogyakarta: BPFE

Susilowati., E dan Sinaga., H. 2019. Pengaruh Laba Bersih, Arus Kas Dan Dividen Tunai Terhadap Volume Perdagangan Saham Pada Perusahaan Publik Sektor Barang Dan Konsumsi Di BEI. JMK (Jurnal Manajemen dan Kewirausahaan) Vol 4 No. 1

Tandelilin, Aduardus. 2011. Portofolio dan investsi. Yogyakarta: Konisius

Utomo., St. Dwiarso dan Pamungkas, Imang Dapit. 2018. Cash Flow Activities And Stock Returns In Manufacturing Of Indonesia: A Moderating Role Of Earning Management. Academy of Accounting and Financial Studies Journal Vol. 22, No. 6 